\title{
EFFECTS OF DIFFERENT SEEDING RATES ON FORAGE YIELD AND QUALITY COMPONENTS IN PEA
}

\author{
Aysen UZUN ${ }^{*}$, Barls B. ASIK², Esvet ACIKGOZ ${ }^{1}$ \\ ${ }^{1}$ Uludag University, Faculty of Agriculture, Department of Field Crops, Bursa, TURKEY \\ ${ }^{2}$ Uludag University, Department of Soil Science and Plant Nutrition, Bursa, TURKEY \\ *Corresponding author: uzunay@uludag.edu.tr
}

Received: 03.03.2017

\begin{abstract}
The aim of this study was to investigate the effects of seeding rate on yield and quality components in forage pea cultivars. Four pea cultivars (Ulubatli, Kirazli, Golyazi and Urunlu) and five seeding rates $(75,100,125$, 150 and 175 viable seeds $\mathbf{m}^{-2}$ ) were used in this study. Field experiments were carried out from 2009 to 2011 during the winter growth period at Uludag University, Faculty of Agriculture, Agricultural Research and Application Center in Bursa province, Turkey. The experimental design was a randomized complete block desing with three replications. Dry matter yield, crude protein ratio and yield, acid detergent fiber, neutral detergent fiber, total digestible nutrients and relative feed values were determined. Significant differences were found among the pea cultivars and seeding rates in all measured characteristics in both years. The highest dry matter yield was obtained from the Kirazli cultivar at 125 seed $\mathrm{m}^{-2}$. The digestibility of the Golyazi cultivar was higher than the other cultivars. On the other hand, the digestibility of the forage decreased as the seeding rate increased.
\end{abstract}

Keywords: cultivars, dry matter yield, pea, Pisum sativum, seeding rates

\section{INTRODUCTION}

Pea (Pisum sativum L.) is an annual cool-season legume crop that can be grown as a pulse or forage crop. This plant is generally grown to provide forage and seed in Turkey. Forage pea is usually grown for hay, pasture, green manure and silage production. Pea is also used as an alternative protein source in the animal feed industry in Europe (Tan et al., 2012); plants have high levels of quality protein, are rich in phosphorus and calcium, and are a good source of vitamins, especially vitamins A and D. These qualities make field pea one of the best feeds for animals and almost indispensable for efficient, economical livestock feeding (Tekeli and Ates, 2003.) On the other hand, forage pea is a very suitable crop in an annual crop rotation because it provides biological nitrogen for the plants sown after them (Tan et al., 2012).

Genotypes, agronomical management, and soil and climate factors can affect plant growth, yield and quality. Determining the optimal seeding rate is an important factor. Seeding rates can affect crop yield, competitive ability with weeds, soil surface evaporation, and light interception (Johnston et al., 2002; Al-Rifaee et al., 2004; Armstrong et al., 2008; Yavuz et al., 2011; Biswas et al., 2012).
Optimum seeding rates in pea ranged greatly depending on genotypes, growing purposes and climatic conditions (Davies et al., 1985; Uzun and Acikgoz, 1998). Several studies have been conducted to determine the effects of seeding rate on yield and quality in grain legumes (Martin et al., 1994; Uzun and Acikgoz, 1998; Tawaha and Turk, 2001). Previous studies with different legumes species indicated that yield usually increases with increasing seeding rate (Baswana and Saharan, 1993; Dwivedi et al., 1998; Auskalnis and Dovydaitis, 1998; Uzun and Acikgoz, 1998). On the other hand, some studies on field pea or another legume crops have shown that yield usually increases with an increasing seeding rate until it reaches an optimum seeding rate and then decreases (Brathwaite, 1982; Townley Smith and Wright, 1994; Jovaisiene et al., 1998).

Pea varieties are widely grown in Marmara Region of Turkey for fresh, frozen and dry grains. Pea has started to gain importance as animal feed in Turkey and Bursa in recent years. The effects of seeding rate on yield and quality of pea have been reported in some research. However, very limited information is available on the optimum seeding rate. This study was conducted to determine the effects of seeding rate on yield and quality 
components in four field pea cultivars. Additionally, this research determined the optimum seeding rate for field pea.

\section{MATERIALS AND METHODS}

Field trials were conducted in 2009-2010 and 20102011 in experimental plots at the Uludag University, Faculty of Agriculture, Department of Field Crops in Bursa province located in Marmara Region to determine the effects of seeding rate on yield and yield components of field pea cultivars and to determine the optimum seeding rate. The experimental fields were located in the coastal area of northwest Turkey, $70 \mathrm{~m}$ above sea level. In the trial area, according to the State Meteorology Department, the mean temperatures recorded during the plant growth period (from November to June) were 10.0, 9.8, 6.6, 9.4, 9.0, 13.5, 19.3 and $22.7^{\circ} \mathrm{C}$ (average $12.5^{\circ} \mathrm{C}$ ) in 2009-2010 and 15.5, 9.5, 5.8, 6.1, 8.2, 10.6, 16.8 and
22.2 ${ }^{\circ} \mathrm{C}$ (average $11.8{ }^{\circ} \mathrm{C}$ ) in $2010-2011$. The total precipitation through the pea growth period (from November to June) was $80.6,119.1,149.7,178.9,115.3$, $63.4,29.4$, and $135.2 \mathrm{~mm}$ (total $871.6 \mathrm{~mm}$ ) in 2009-2010 and $24.0,152.6,72.4,18.4,67.4,76.8,27.3$, and $14.0 \mathrm{~mm}$ (total $452.9 \mathrm{~mm}$ ) in $2010-2011$. For the period of this experiment, the relative humidity values during the plant growth period were $74.9 \%$ in $2009-2010$ and $74.8 \%$ in 2010-2011. The average long-term total precipitation during the plant growth period was $533.2 \mathrm{~mm}$; the mean temperature was $11.3^{\circ} \mathrm{C}$, and the relative humidity was $68.1 \%(1975-2008)$ (Table 1). The soil was a clay-loam, slightly alkaline (pH: 7.79-8.03), salt-free (EC: 390$\left.652 \mu \mathrm{S} \mathrm{cm} \mathrm{cm}^{-1}\right)$, poor in organic matter (1.35-1.82 $\%)$, adequate in terms of nitrogen $(0.098-0.127 \%)$ rich in phosphorus (31.85-62.03 $\mathrm{mg} \mathrm{kg}^{-1}$ ) and potassium (0.685$\left.1.246 \mathrm{meq} 100 \mathrm{~g}^{-1}\right)$, and adequate in terms of micronutrients $(\mathrm{Cu}, \mathrm{Mn}$ and $\mathrm{Fe})$, except $\mathrm{Zn}$.

Table 1. Temperature, precipitation and relative humidity values of experimental years and long-term (1975-2008) growing seasons in Bursa-Turkey.

\begin{tabular}{|c|c|c|c|c|c|c|c|c|c|}
\hline \multirow{2}{*}{ Month } & \multicolumn{3}{|c|}{ Temperature $\left({ }^{0} \mathrm{C}\right)$} & \multicolumn{3}{|c|}{ Precipitation (mm) } & \multicolumn{3}{|c|}{ Relative Humidity (\%) } \\
\hline & $\begin{array}{c}2009 / \\
2010 \\
\end{array}$ & $\begin{array}{l}2010 / \\
2011 \\
\end{array}$ & $\begin{array}{l}\text { Long } \\
\text { Term } \\
\end{array}$ & $\begin{array}{c}2009 / \\
2010 \\
\end{array}$ & $\begin{array}{c}2010 / \\
2011 \\
\end{array}$ & $\begin{array}{l}\text { Long } \\
\text { Term } \\
\end{array}$ & $\begin{array}{c}2009 / \\
2010 \\
\end{array}$ & $\begin{array}{l}2010 / \\
2011 \\
\end{array}$ & $\begin{array}{l}\text { Long } \\
\text { Term } \\
\end{array}$ \\
\hline November & 10,0 & 15,5 & 10,3 & 80,6 & 24,0 & 85,4 & 84,5 & 68,6 & 72,4 \\
\hline December & 9,8 & 9,5 & 7,1 & 119,1 & 152,6 & 96,4 & 77,7 & 79,8 & 71,7 \\
\hline January & 6,6 & 5,8 & 5,4 & 149,7 & 72,4 & 80,3 & 77,3 & 81,5 & 71,2 \\
\hline February & 9,4 & 6,1 & 5,9 & 178,9 & 18,4 & 66,2 & 77,4 & 74,4 & 69,6 \\
\hline March & 9,0 & 8,2 & 8,5 & 115,3 & 67,4 & 62,7 & 77,8 & 77,0 & 68,9 \\
\hline April & 13,5 & 10,6 & 13,0 & 63,4 & 76,8 & 65,2 & 71,3 & 78,3 & 67,1 \\
\hline May & 19,3 & 16,8 & 17,7 & 29,4 & 27,3 & 43,4 & 64,3 & 75,7 & 64,8 \\
\hline June & 22,7 & 22,2 & 22,4 & 135,2 & 14,0 & 33,6 & 68,8 & 63,3 & 58,7 \\
\hline Total/Mean & 12,5 & 11,8 & 11,3 & 871,6 & 452,9 & 533,2 & 74,9 & 74,8 & 68,1 \\
\hline
\end{tabular}

The experimental design was a randomized complete block desing with three replications. Four pea cultivars (Ulubatli, Kirazli, Golyazi and Urunlu), officially registered in Turkey in 2007 , were grown in all possible combinations of five seeding rates $(75,100,125,150$ and 175 viable seeds $\mathrm{m}^{-2}$ ). The seeds of the field pea cultivars were sown with an Oyjort experimental drill. The plot size was $1.4 \times 10=14 \mathrm{~m}^{-2}$, which consisted of 8 rows spaced at $17.5 \mathrm{~cm}$. The previous crop was wheat in both years of the study. Before seeding (23 November 2009 and 11 November 2010), $30 \mathrm{~kg} \mathrm{~N} \mathrm{ha}^{-1}$ was applied. Weeds were controlled by hand as needed. No irrigation was applied during the growing season.

In this study, at the beginning of podding, a $2 \mathrm{~m}^{2}$ section of each plot was harvested for forage yield, and $500 \mathrm{~g}$ samples from each plot were dried at $70^{\circ} \mathrm{C}$ for $48 \mathrm{~h}$. Nitrogen as determined by the micro Kjeldahl technique on duplicate dry matter and seed samples for each treatment. Crude protein content $(\mathrm{N} \times 6.25)$ and crude protein yield were calculated. ADF (acid-detergent fiber) and NDF (neutral-detergent fiber) ratios were measured according to the methods from Ankom Technology (ANKOM 200/220 Fiber Analyzer, Ankom Technology
Corp., Fairport, NY, USA). Total digestible nutrients (TDN) and relative feed value (RFV) were estimated according to the following equations (Lithourgidis et al. 2006):

$$
\begin{aligned}
& \mathrm{TDN}=(-1.291 \times \mathrm{ADF})+101.35 \\
& \mathrm{RFV}=\% \text { DDM } \times \text { \% DMI } \times 0.775
\end{aligned}
$$

An analysis of variance was carried out using JMP 5.0.1 (SAS 1989-2002). The statistical significance of the treatments was determined at the 0.05 and 0.01 probability levels using the F-test.

\section{RESULTS AND DISCUSSION}

In this study, the effects of seeding rate on dry matter yield, crude protein ratio, crude protein yield, acid detergent fiber, neutral detergent fiber, total digestible nutrients and relative feed value characteristics in four forage pea cultivars were determined. These data are shown below.

Dry Matter Yield: The analysis of variance indicated that cultivars, seeding rates and the cultivars $\mathrm{x}$ seeding rates interaction were significantly affected by dry matter yield in 2009-2010 and 2010-2011. 
As seen in Table 2, the highest dry matter yield was obtained from the Kirazli cultivar in both years. Dry matter yields were from 7494.0 to $9792.0 \mathrm{~kg} \mathrm{ha}^{-1}$, respectively, in 2010 and 2011 for the Kirazlı variety. The average dry matter yield of the Kirazlı cultivar varied from 419 to $860 \mathrm{~kg} \mathrm{ha}$ in previous experiments conducted in the same (Uzun et al., 2005; Acikgoz et al., 2009) and different (Timuragaoglu et al., 2004; Turk et al., 2011) locations. In the first year $\left(7947.3 \mathrm{~kg} \mathrm{ha}^{-1}\right)$ and the second year $\left(10526.3 \mathrm{~kg} \mathrm{ha}^{-1}\right)$, the highest dry matter yields were achieved at 125 seed $\mathrm{m}^{-2}$. Dry matter yields decreased as seeding rates increased in our study. In this study, lateral branch and shoot number were decreased with increased seeding rates (especially at 150-175 seed $\mathrm{m}^{-2}$ ) in both years. Heath and Hebblethwaite (1987) reported that pea yield decreased at very high plant densities. Some researchers reported that the number of branches in a plant increased with a decrease in plant population (Heath et al., 1991; Knott and Belcher, 1998).

Table 2. Mean values of dry matter yield measured in different cultivars and seeding rates

\begin{tabular}{|c|c|c|c|c|c|c|}
\hline \multirow[b]{2}{*}{ Seeding Rates/ Cultivars } & \multicolumn{4}{|c|}{ Dry Matter Yield $\left(\mathrm{kg} \mathrm{ha}^{-1}\right)$} & \multirow[b]{2}{*}{175} & \multirow[b]{2}{*}{ Means } \\
\hline & 75 & 100 & 125 & 150 & & \\
\hline \multicolumn{7}{|c|}{ 2009-2010 } \\
\hline ULUBATLI & $5243,6 \mathrm{ij}^{*}$ & $6659,0 \mathrm{ef}$ & $6674,7 \mathrm{~d}-\mathrm{f}$ & 5475,71 & $4639,2 \mathrm{k}$ & $5738,4 \mathrm{D}$ \\
\hline KIRAZLI & $7261,3 \mathrm{c}$ & $8260,2 \mathrm{~b}$ & $9317,4 \mathrm{a}$ & $6752,2 \mathrm{de}$ & $5879,0 \mathrm{~h}$ & $7494,0 \mathrm{~A}$ \\
\hline GOLYAZI & $6943,4 \mathrm{~d}$ & $7307,9 \mathrm{c}$ & $8452,7 \mathrm{~b}$ & $6446,8 \mathrm{fg}$ & $5186,9 \mathrm{j}$ & $6867,5 \mathrm{~B}$ \\
\hline URUNLU & $5875,0 \mathrm{~h}$ & $6360,0 \mathrm{~g}$ & $7344,6 \mathrm{c}$ & $5860,6 \mathrm{~h}$ & $4575,9 \mathrm{k}$ & $6003,2 \mathrm{C}$ \\
\hline Means & $6330,8 \mathrm{C}$ & $7146,8 \mathrm{~B}$ & $7947,3 \mathrm{~A}$ & $6133,8 \mathrm{D}$ & $5070,2 \mathrm{E}$ & \\
\hline $\operatorname{LSD}(\% 5)$ & C: 122,44 & SR: 136,88 & CxSR: 2 & & & \\
\hline \multicolumn{7}{|c|}{ 2010-2011 } \\
\hline ULUBATLI & $6714,4 j$ & $8464,0 \mathrm{e}-\mathrm{g}$ & $10096,8 \mathrm{bc}$ & $8670,2 \mathrm{e}-\mathrm{g}$ & $7329,3 \mathrm{~h}-\mathrm{j}$ & $8255,0 \mathrm{C}$ \\
\hline KIRAZLI & $8503,2 \mathrm{e}-\mathrm{g}$ & $10746,5 \mathrm{~b}$ & $11499,1 \mathrm{a}$ & $9967,7 \mathrm{c}$ & $8243,4 \mathrm{fg}$ & $9792,0 \mathrm{~A}$ \\
\hline GOLYAZI & $7990,1 \mathrm{gh}$ & $9841,4 \mathrm{~cd}$ & $10412,7 \mathrm{bc}$ & 8866,3 ef & $8019,4 \mathrm{gh}$ & $9026,0 \mathrm{~B}$ \\
\hline URUNLU & $7154,1 \mathrm{ij}$ & $9145,1 \mathrm{de}$ & $10096,5 \mathrm{bc}$ & $7427,7 \mathrm{~h} 1$ & $5718,7 \mathrm{k}$ & $7908,4 \mathrm{D}$ \\
\hline Means & $7590,4 \mathrm{D}$ & $9549,3 \mathrm{~B}$ & $10526,3 \mathrm{~A}$ & $8733,0 \mathrm{C}$ & 7327,7 D & \\
\hline $\operatorname{LSD}(\% 5)$ & C: 313,53 & SR:350,53 & \multicolumn{2}{|c|}{ CxSR:701,08 } & & \\
\hline
\end{tabular}

*: Means followed by the same letter are not significantly different at $\mathrm{P}<0.05$, using the LSD test.

In the cultivar $\mathrm{x}$ seeding rate interaction, the highest dry matter yield was produced by Kirazli at 125 seed $\mathrm{m}^{-2}$ with $9317.4 \mathrm{~kg} \mathrm{ha}^{-1}$ in the first growing season and with11499.1 $\mathrm{kg} \mathrm{ha}^{-1}$ in the second growing season. In the second year, dry matter yield was higher than in the first year. In the years when the research was conducted, the rainfall decreased in the second year in May. The main reason for the increase in yield is low temperature. This situation can be discussed by supporting with different sources (Ayaz et al., 2004).

Crude Protein Ratio: The analysis of variance indicated that cultivars, seeding rates and the cultivar $\mathrm{x}$ seeding rates interaction significantly affected the crude protein ratio in the 2009-2010 year. In the 2010-2011 year, there were important differences between cultivars and seeding rates (Table 3 ).

Urunlu had the highest crude protein ratio for both the first year $(18.69 \%)$ and second year $(18.64 \%)$ because this variety had normal leaves and a high number of leaflets. The crude protein ratio increased from 75 seed $\mathrm{m}^{-}$ ${ }^{2}$ to 125 seed $\mathrm{m}^{-2}$ and then decreased in the first and second years, and the highest crude protein ratio was determined at $125 \mathrm{seed} \mathrm{m}^{-2}$. In the cultivar $\mathrm{x}$ seeding rate interaction, the crude protein ratio obtained at 125 seed $\mathrm{m}^{-2}$ with the Urunlu cultivar was the highest at $19.84 \%$ in first year

(Table 2). The average crude protein ratio of our results was lower (Kadıoğlu 2011) or similar (Timuragaoğlu et al. 2004) than that in previous experiments.

Forage crude protein content is a very important quality factor. The higher the crude protein value of forage, the higher the quality (Lithourgidis et al. 2006).

Crude Protein Yield: As shown in Table 4, the main effects and the cultivars $\mathrm{x}$ seeding rates interaction were statistically significant for the crude protein yield characteristic.

In first year, Kirazli had the highest crude protein yield $\left(1255.3 \mathrm{~kg} \mathrm{ha}^{-1}\right)$. In the second year, the highest crude protein yield was obtained from the Kirazli (1620.2 $\mathrm{kg} \mathrm{ha}^{-}$ 1) and Golyazi (1604.3 kg ha-1) varieties. The highest crude protein yield was found at 125 seed $\mathrm{m}^{-2}$ due to higher dry matter yield in both the first year $(1434.3 \mathrm{~kg}$ $\mathrm{ha}^{-1}$ ) and second year (1906.3 $\left.\mathrm{kg} \mathrm{ha}^{-1}\right)$. At $125 \mathrm{seed} \mathrm{m}^{-2}$, the Kirazl1 variety had the highest crude protein yield $\left(1628.3 \mathrm{~kg} \mathrm{ha}^{-1}\right)$ in $2009 / 10$. In the 2010/11 year, the Golyazi (2019.7 kg ha' ${ }^{-1}$, Urunlu (2015.5 $\left.\mathrm{kg} \mathrm{ha}^{-1}\right)$ and 
Kirazli (1935.1 $\mathrm{kg} \mathrm{ha}^{-1}$ ) varieties had the highest crude protein yields at $125 \mathrm{seed}^{-2}$ seeding rate (Table 4).
Crude protein yield describes complete forage quality (Kebede et al. 2014).

Table 3. Mean values of crude protein ratio measured in different cultivars and seeding rates

\begin{tabular}{|c|c|c|c|c|c|c|}
\hline \multirow[b]{2}{*}{$\begin{array}{l}\text { Seeding Rates/ } \\
\text { Cultivars }\end{array}$} & \multicolumn{5}{|c|}{ Crude Protein Ratio (\%) } & \multirow{3}{*}{ Means } \\
\hline & 75 & 100 & 125 & 150 & 175 & \\
\hline \multicolumn{6}{|c|}{ 2009-2010 } & \\
\hline ULUBATLI & $15,1 \mathrm{k}^{*}$ & $15,2 \mathrm{k}$ & $16,0 \mathrm{ij}$ & $16,0 \mathrm{ij}$ & $15,7 \mathrm{j}$ & $15,6 \mathrm{D}$ \\
\hline KIRAZLI & 16,21 & $17,2 \mathrm{gh}$ & $17,5 \mathrm{fg}$ & $17,1 \mathrm{~h}$ & $15,3 \mathrm{k}$ & $16,7 \mathrm{C}$ \\
\hline GOLYAZI & $17,2 \mathrm{gh}$ & $18,0 \mathrm{de}$ & $18,7 \mathrm{c}$ & 17,7 ef & $16,0 \mathrm{ij}$ & $17,5 \mathrm{~B}$ \\
\hline URUNLU & $19,1 \mathrm{~b}$ & $19,3 \mathrm{~b}$ & $19,8 \mathrm{a}$ & $18,1 \mathrm{~d}$ & $17,2 \mathrm{gh}$ & $18,7 \mathrm{~A}$ \\
\hline Means & $16,9 \mathrm{D}$ & $17,4 \mathrm{~B}$ & $18,0 \mathrm{~A}$ & $17,2 \mathrm{C}$ & $16,1 \mathrm{E}$ & \\
\hline $\operatorname{LSD}(\% 5)$ & C: 0,159 & SR: 0,177 & CxSR: 0,356 & & & \\
\hline \multicolumn{7}{|c|}{ 2010-2011 } \\
\hline ULUBATLI & 15,1 & 15,2 & 16,4 & 16,2 & 15,7 & $15,7 \mathrm{C}$ \\
\hline KIRAZLI & 17,1 & 16,6 & 16,9 & 16,4 & 15,7 & $16,5 \mathrm{C}$ \\
\hline GOLYAZI & 17,7 & 18,4 & 19,4 & 16,6 & 16,4 & $17,7 \mathrm{~B}$ \\
\hline URUNLU & 19,0 & 19,0 & 19,9 & 18,3 & 16,9 & $18,6 \mathrm{~A}$ \\
\hline Means & $17,2 \mathrm{AB}$ & $17,3 \mathrm{AB}$ & $18,1 \mathrm{~A}$ & $16,9 \mathrm{BC}$ & $16,2 \mathrm{C}$ & \\
\hline $\operatorname{LSD}(\% 5)$ & C: 0,849 & SR: 0,951 & CxSR: ns & & & \\
\hline
\end{tabular}

*: Means followed by the same letter are not significantly different at $\mathrm{P}<0.05$, using the LSD test., ns: not significant

Table 4. Mean values of crude protein yield measured in different cultivars and seeding rates

\begin{tabular}{|c|c|c|c|c|c|c|}
\hline \multirow[b]{2}{*}{$\begin{array}{l}\text { Seeding Rates/ } \\
\text { Cultivars }\end{array}$} & \multicolumn{5}{|c|}{ Crude Protein Yield (kg ha $\left.{ }^{-1}\right)$} & \multirow{2}{*}{ Means } \\
\hline & 75 & 100 & 125 & 150 & 175 & \\
\hline \multicolumn{7}{|c|}{ 2009-2010 } \\
\hline ULUBATLI & $788,9 \mathrm{mn}^{*}$ & $1013,1 \mathrm{j}$ & 1070,41 & $875,9 \mathrm{kl}$ & 729,2 o & $895,5 \mathrm{D}$ \\
\hline KIRAZLI & $1175,6 \mathrm{fg}$ & $1418,8 \mathrm{c}$ & $1628,3 \mathrm{a}$ & $1153,0 \mathrm{f}-\mathrm{h}$ & $900,9 \mathrm{k}$ & $1255,3 \mathrm{~A}$ \\
\hline GOLYAZI & 1192,4 ef & $1315,7 \mathrm{~d}$ & $1581,4 \mathrm{~b}$ & $1139,0 \mathrm{gh}$ & $830,8 \mathrm{~lm}$ & $1211,9 \mathrm{~B}$ \\
\hline URUNLU & $1121,9 \mathrm{~h}$ & 1226,9 e & $1457,1 \mathrm{c}$ & 1059,51 & $784,7 \mathrm{n}$ & $1130,0 \mathrm{C}$ \\
\hline Means & $1069,7 \mathrm{C}$ & $1243,6 \mathrm{~B}$ & $1434,3 \mathrm{~A}$ & $1056,8 \mathrm{C}$ & $811,4 \mathrm{D}$ & \\
\hline $\operatorname{LSD}(\% 5)$ & $\mathrm{C}: 20,34$ & SR: 22,76 & CxSR: 45,49 & & & \\
\hline \multicolumn{7}{|c|}{ 2010-2011 } \\
\hline ULUBATLI & $1017,3 \mathrm{~h}$ & $1287,5 \mathrm{fg}$ & $1654,8 \mathrm{~cd}$ & $1407,7 \mathrm{f}$ & $1148,2 \mathrm{gh}$ & $1303,1 \mathrm{C}$ \\
\hline KIRAZLI & 1455,9 ef & $1790,3 \mathrm{bc}$ & $1935,1 \mathrm{ab}$ & $1631,0 \mathrm{c}-\mathrm{e}$ & $1288,7 \mathrm{fg}$ & $1620,2 \mathrm{~A}$ \\
\hline GOLYAZI & $1407,9 \mathrm{f}$ & $1805,6 \mathrm{bc}$ & 2019,7 a & $1469,6 \mathrm{~d}-\mathrm{f}$ & $1318,5 \mathrm{fg}$ & $1604,3 \mathrm{~A}$ \\
\hline URUNLU & $1353,7 \mathrm{f}$ & $1737,0 \mathrm{c}$ & $2015,5 \mathrm{a}$ & $1359,4 \mathrm{f}$ & $972,8 \mathrm{~h}$ & $1487,7 \mathrm{~B}$ \\
\hline Means & $1308,7 \mathrm{D}$ & $1655,1 \mathrm{~B}$ & $1906,3 \mathrm{~A}$ & $1466,9 \mathrm{C}$ & $1182,1 \mathrm{E}$ & \\
\hline $\operatorname{LSD}(\% 5)$ & $\mathrm{C}: 87,12$ & SR: 97,41 & CxSR:194,85 & & & \\
\hline
\end{tabular}

Crude protein yields between 63 and $149 \mathrm{~kg} \mathrm{da}^{-1}$ were observed in previous studies (Uzun and Acikgoz, 1998; Uher et al., 2008; Turk et al., 2011; Kocer and Albayrak,
2012). Timuragaoglu et al., (2004), Uzun et al., (2005) and Kadıoğlu (2011) determined crude protein yields in the Kirazli variety at $76 \mathrm{~kg} \mathrm{da}^{-1}, 110 \mathrm{~kg} \mathrm{da}^{-1}$, and $56 \mathrm{~kg} \mathrm{da}^{-}$ 
${ }^{1}$, respectively. Turk et al. (2011) found that the highest crude protein yield was obtained at 150 seed $\mathrm{m}^{-2}$. The reason for these differences were different cultivars, sowing seasons and climatic factors.

Acid Detergent Fiber (ADF): Cultivars and seeding rates were statistically significant for acid detergent fiber in the 2009-2010 and 2010-2011 years (Table 5).

The ADF content of the Golyazı variety was lower than the other varieties, and ADF content increased with increasing seeding rates in both years. If the ADF value is low, forage is more digestible. Therefore, a low ADF value is desirable. The ADF content of the Golyazı variety was $27.45 \%$ in first year and $27.64 \%$ in the second year. The ADF content was $29.57 \%$ at the 175 seed $\mathrm{m}^{-2}$ seeding rate in the first year. In the second year, the ADF content was $31.61 \%$ and $32.39 \%$ at the 150 and 175 seed $\mathrm{m}^{-2}$ seeding rates, respectively (Table 5). Since dry matter yields were higher in the second year, the observed ADF contents were higher.

Table 5. Mean values of ADF measured in different cultivars and seeding rates

\begin{tabular}{lcccccc}
\hline & \multicolumn{7}{c}{ ADF (\%) } & Means \\
\cline { 2 - 6 } $\begin{array}{l}\text { Seeding Rates/ } \\
\text { Cultivars }\end{array}$ & 75 & 100 & 125 & 150 & 175 & \\
\hline
\end{tabular}

2009-2010

\begin{tabular}{|c|c|c|c|c|c|c|}
\hline ULUBATLI & 28,8 & 29,1 & 28,8 & 29,4 & 29,8 & $29,2 \mathrm{~A}^{*}$ \\
\hline KIRAZLI & 27,4 & 27,2 & 28,3 & 29,2 & 29,3 & $28,3 \mathrm{AB}$ \\
\hline GOLYAZI & 23,9 & 26,5 & 28,6 & 28,6 & 29,6 & $27,5 \mathrm{~B}$ \\
\hline URUNLU & 26,2 & 28,2 & 28,3 & 29,5 & 29,6 & $28,4 \mathrm{AB}$ \\
\hline Means & $26,6 \mathrm{D}$ & $27,7 \mathrm{C}$ & $28,5 \mathrm{BC}$ & $29,2 \mathrm{AB}$ & $29,6 \mathrm{~A}$ & \\
\hline
\end{tabular}

LSD (\%5) C: $0,920 \quad$ SR: $1,028 \quad$ CXSR:ns

2010-2011

$\begin{array}{lllllll}\text { ULUBATLI } & 27,7 & 28,1 & 30,3 & 30,8 & 31,5 & 29,7 \mathrm{~B} \\ \text { KIRAZLI } & 29,0 & 30,1 & 31,0 & 33,4 & 34,1 & 31,5 \mathrm{~A} \\ \text { GOLYAZI } & 24,2 & 26,2 & 27,7 & 29,5 & 30,6 & 27,6 \mathrm{C} \\ \text { URUNLU } & 28,3 & 30,0 & 31,3 & 32,7 & 33,4 & 31,2 \mathrm{~A} \\ \text { Means } & 27,3 \mathrm{D} & 28,6 \mathrm{C} & 30,1 \mathrm{~B} & 31,6 \mathrm{~A} & 32,4 \mathrm{~A} & \end{array}$

LSD (\%5) C: $0,738 \quad$ SR:0,823 CxSR: ns

*: Means followed by the same letter are not significantly different at $\mathrm{P}<0.05$, using the LSD test., ns: not significant

The ADF fraction includes cellulose with lignin, and it is a slowly digestible material in forage (Acikgoz et al., 2013; Kebede et al., 2014). As ADF increases, forage quality declines (Joachim and Jung, 1997; Albayrak et al., 2011). In this study, the ADF values were generally under $31 \%$ and this value corresponded to prime quality according to the forage standard (Yavuz et al., 2009). ADF ratios varied from 21 to $27 \%$ in previous studies (Kadioglu, 2011; Kocer and Albayrak, 2012). Additionally, Tan et al., (2014) reported that the effects of seeding rate on the ADF ratio of pea were significant.

Neutral Detergent Fiber (NDF): Only the main effects were statistically significant for the neutral detergent fiber characteristic in the 2009-2010 and 2010-2011 years (Table 6).

The lowest NDF content was obtained in the Golyazi variety in both the first year $(30.16 \%)$ and second year $(39.34 \%)$. If the NDF value increases, dry matter intake generally decreases, and the rumination period increases (Van Soest et al., 1991; Albayrak et al., 2011; Acikgoz et al., 2013; Kebede et al., 2014). In this study, NDF content decreased according to decreasing seeding rates in both

years. NDF content was $29.49 \%$ and $38.84 \%$ at the 75 seed $\mathrm{m}^{-2}$ seeding rate in the first and second years, respectively (Table 6). The NDF values were higher in the second year than in the first year because dry matter yields were high.

The NDF fraction includes cellulose, lignin and hemicellulose, and as with ADF, this value is an important factor in determining forage quality. When NDF content decreases, dry matter intake will increase (Joachim and Jung, 1997; Albayrak and Turk, 2013; Acikgoz et al., 2013; Kebede et al., 2014). Our results were similar to the NDF ratios reported by other researchers (Kadioglu, 2011; Kocer and Albayrak, 2012; Tan et. al., 2014).

Total Digestible Nutrients (TDN): The main effects were statistically significant for total digestible nutrients characteristic in both years (Table 7). 
The Golyazi variety had the highest TDN value in first year $(65.92 \%)$ and second year $(65.66 \%)$. In both the first year $(67.04 \%)$ and second year $(66.10 \%)$, the TDN value was the highest at the 75 seed $\mathrm{m}^{-2}$ seeding rate (Table 7).

Table 6. Mean values of NDF measured in different cultivars and seeding rates

\begin{tabular}{|c|c|c|c|c|c|c|}
\hline \multirow[b]{2}{*}{ Seeding Rates/ Cultivars } & \multicolumn{4}{|c|}{ NDF (\%) } & \multirow[b]{2}{*}{175} & \multirow{2}{*}{ Means } \\
\hline & 75 & 100 & 125 & 150 & & \\
\hline \multicolumn{7}{|c|}{ 2009-2010 } \\
\hline ULUBATLI & 27,5 & 28,8 & 29,6 & 32,3 & 33,7 & $30,4 C^{*}$ \\
\hline KIRAZLI & 31,4 & 31,9 & 32,5 & 32,9 & 33,1 & $32,4 \mathrm{~B}$ \\
\hline GOLYAZI & 28,1 & 28,7 & 30,4 & 31,5 & 32,1 & $30,2 \mathrm{C}$ \\
\hline URUNLU & 31,0 & 32,9 & 33,5 & 34,8 & 34,9 & $33,4 \mathrm{~A}$ \\
\hline Means & $29,5 \mathrm{D}$ & $30,6 \mathrm{C}$ & $31,5 \mathrm{~B}$ & $32,9 \mathrm{~A}$ & $33,4 \mathrm{~A}$ & \\
\hline $\operatorname{LSD}(\% 5)$ & C: 0,740 & SR: 0,854 & CxSR: ns & & & \\
\hline \multicolumn{7}{|c|}{ 2010-2011 } \\
\hline ULUBATLI & 39,2 & 41,6 & 43,6 & 44,2 & 44,3 & $42,6 \mathrm{~B}$ \\
\hline KIRAZLI & 41,1 & 42,1 & 44,1 & 44,5 & 46,1 & $43,6 \mathrm{~A}$ \\
\hline GOLYAZI & 36,4 & 37,6 & 38,5 & 41,4 & 42,8 & $39,3 \mathrm{C}$ \\
\hline URUNLU & 38,7 & 40,1 & 42,6 & 43,7 & 44,3 & $41,9 \mathrm{~B}$ \\
\hline Means & $38,8 \mathrm{E}$ & $40,3 \mathrm{D}$ & $42,2 \mathrm{C}$ & $43,5 \mathrm{~B}$ & $44,4 \mathrm{~A}$ & \\
\hline LSD (\%5) & C: 0,820 & SR: 0,917 & CxSR: ns & & & \\
\hline
\end{tabular}

Table 7. Mean values of TDN measured in different cultivars and seeding rates

\begin{tabular}{|c|c|c|c|c|c|c|}
\hline \multirow{2}{*}{$\begin{array}{l}\text { Seeding Rates/ } \\
\text { Cultivars }\end{array}$} & \multicolumn{5}{|c|}{ TDN (\%) } & \multirow{2}{*}{ Means } \\
\hline & 75 & 100 & 125 & 150 & 175 & \\
\hline \multicolumn{7}{|c|}{ 2009-2010 } \\
\hline ULUBATLI & $64,2^{*}$ & 63,8 & 64,2 & 63,4 & 62,9 & 63,7 B \\
\hline KIRAZLI & 65,9 & 66,3 & 64,8 & 63,7 & 63,5 & $64,8 \mathrm{AB}$ \\
\hline GOLYAZI & 70,5 & 67,2 & 64,5 & 64,4 & 63,1 & $65,9 \mathrm{~A}$ \\
\hline URUNLU & 67,6 & 64,9 & 64,8 & 63,3 & 63,1 & $64,7 \mathrm{AB}$ \\
\hline Means & $67,0 \mathrm{~A}$ & $65,6 \mathrm{~B}$ & $64,5 \mathrm{BC}$ & $63,7 \mathrm{CD}$ & $63,2 \mathrm{D}$ & \\
\hline LSD (\%5) & C: 1,188 & SR: 1,327 & CxSR: ns & & & \\
\hline \multicolumn{7}{|c|}{ 2010-2011 } \\
\hline ULUBATLI & 65,6 & 65,1 & 62,3 & 61,5 & 60,7 & $63,6 \mathrm{~B}$ \\
\hline KIRAZLI & 63,9 & 62,4 & 61,3 & 58,3 & 57,3 & $60,6 \mathrm{C}$ \\
\hline GOLYAZI & 70,1 & 67,6 & 65,6 & 63,2 & 61,9 & $65,7 \mathrm{~A}$ \\
\hline URUNLU & 64,8 & 62,6 & 60,9 & 59,1 & 58,2 & $61,1 \mathrm{C}$ \\
\hline Means & $66,1 \mathrm{~A}$ & $64,4 \mathrm{~B}$ & $62,5 \mathrm{C}$ & $60,6 \mathrm{D}$ & $59,5 \mathrm{D}$ & \\
\hline LSD (\%5) & C: 0,951 & SR:1,062 & CxSR: ns & & & \\
\hline
\end{tabular}

*: Means followed by the same letter are not significantly different at $\mathrm{P}<0.05$, using the LSD test., ns: not significant

TDN represents the ratio of the forage that can be digested by livestock. The TDN ratio is correlated with the ADF concentration of forage. As the ADF rate increases, the TDN ratio decreases. Therefore, the

digestibility of the forage is significantly reduced (Robinson et al., 1998; Y1lmaz et al., 2015; Acikgoz et al.,
2013). Our results were in close agreement with Berti and Zwinger, (2011) and Kocer and Albayrak, (2012).

Relative Feed Value (RFV): Only the main effects were statistically significant for the total relative feed value in both years (Table 8 ). 
The Golyazi (209.07 \%) and Ulubatli (204.06 \%) varieties had the highest RFV values in the first year. In the second year, the highest RFV value was obtained by the Golyazi variety $(160.23 \%)$. In both the first year $(216.11 \%)$ and second year $(162.40 \%)$, the RFV value was the highest at the 75 seed $\mathrm{m}^{-2}$ seeding rate (Table 8). RFV is a value used in estimating the intake and energy value of forage. RFV values of forages over 151, between
$150-125,124-103,102-87,86-75$, and less than 75 are classified as prime, premium, good, fair, poor and rejected, respectively (Uzun, 2010; Kiraz, 2011; Acikgoz et al., 2013; Albayrak and Turk, 2013). In our study, by cultivar and seeding rate, the RFV values corresponded to prime quality. Berti and Zwinger, (2011) and Kocer and Albayrak, (2012) indicated that the average RFV value of pea was 151 and 167 , respectively.

Table 8. Mean values of RFV measured in different cultivars and seeding rates

\begin{tabular}{lcccccc}
\hline & \multicolumn{7}{c}{ RFV $(\%)$} & Means \\
\cline { 2 - 6 } $\begin{array}{l}\text { Seeding Rates/ } \\
\text { Cultivars }\end{array}$ & 75 & 100 & 125 & 150 & 175 &
\end{tabular}

2009-2010

$\begin{array}{lllllll}\text { ULUBATLI } & 225,1 & 214,5 & 208,8 & 190,6 & 181,3 & 204,1 \mathrm{~A}^{*} \\ \text { KIRAZLI } & 200,7 & 197,9 & 191,3 & 186,8 & 185,8 & 192,5 \mathrm{~B} \\ \text { GOLYAZI } & 233,1 & 221,2 & 203,9 & 196,6 & 190,6 & 209,1 \mathrm{~A} \\ \text { URUNLU } & 205,6 & 189,3 & 185,7 & 176,5 & 175,7 & 186,6 \mathrm{C} \\ \text { Means } & 216,1 \mathrm{~A} & 205,8 \mathrm{~B} & 197,4 \mathrm{C} & 187,6 \mathrm{D} & 183,4 \mathrm{D}\end{array}$

LSD (\%5) C: $5,668 \quad$ SR: $6,323 \quad$ CxSR: ns

2010-2011

\begin{tabular}{|c|c|c|c|c|c|c|}
\hline ULUBATLI & 160,1 & 149,9 & 139,4 & 136,5 & 135,2 & $144,2 \mathrm{~B}$ \\
\hline KIRAZLI & 150,1 & 144,8 & 136,6 & 131,5 & 125,7 & $137,7 \mathrm{C}$ \\
\hline GOLYAZI & 178,9 & 169,5 & 163,0 & 148,2 & 141,5 & $160,2 \mathrm{~A}$ \\
\hline URUNLU & 160,5 & 152,1 & 140,9 & 134,9 & 132,1 & $144,1 \mathrm{~B}$ \\
\hline Means & $162,4 \mathrm{~A}$ & $154,1 \mathrm{~B}$ & $144,9 \mathrm{C}$ & $137,8 \mathrm{D}$ & $133,6 \mathrm{E}$ & \\
\hline
\end{tabular}

LSD (\%5) C: $3,218 \quad$ SR: $3,597 \quad$ CxSR: ns

\footnotetext{
*: Means followed by the same letter are not significantly different at $\mathrm{P}<0.05$, using the LSD test., ns: not significant
}

In this study, the effects of seeding rate on forage yield and quality in four forage pea cultivars under Bursa conditions were determined. According to this study and considering the cultivar $\mathrm{x}$ seeding rate interaction, the Kirazli cultivar at a 125 seed $\mathrm{m}^{-2}$ seeding rate was suggested for higher hay yield and higher hay quality. The digestibility of the Golyazi cultivar was higher than the other cultivars. In addition, 125 seed $\mathrm{m}^{-2}$ was determined to be the optimum seeding rate for forage yield in pea.

\section{ACKNOWLEDGEMENTS}

This research was supported by The Scientific Research Projects Unit of Uludag University (Project No: 2010/15). The authors wish to thank American Journal Experts for the final editing of the manuscript.

\section{LITERATURE CITED}

Acikgoz, E., A. Ustun, I. Gul, E. Anlarsal, A. S. Tekeli, I. Nizam, R. Avcioglu, H. Geren, S. Cakmakci, B. Aydinoglu, C. Yucel, M. Avci, Z. Acar, I. Ayan, A. Uzun,U. Bilgili, M. Sincik and M. Yavuz. 2009. Genotype $\times$ environment interaction and stability analysis for drymatter and seed yield in field pea (Pisum sativum L.). Spanish J. Agric. Res. 7(1): 96-106.
Acikgoz, E., M. Sincik, G. Wietgrefe, M. Surmen, S. Cecen, T. Yavuz, C. Erdurmus and A.T. Goksoy. 2013. Dry matter accumulation and forage quality characteristics of different soybean genotypes. Turk. J. Agric. For. 37: 22-32.

Albayrak, S., M. Turk, O. Yuksel and M. Yilmaz. 2011. Forage yield and the quality of perennial legume-grass mixtures under rainfed conditions. Not. Bot. Hort. Agrobot. Cluj. 39(1): 114-118.

Albayrak, S. and M. Turk. 2013. Changes in the forage yield and quality of legume-grass mixtures throughout a vegetation period. Turk. J. Agric. For. 37: 139-147.

Al-Rifaee, M., M.A. Turk and A.R.M. Tawaha. 2004. Effect of seed size and plant population density on yield and yield components of local faba bean (Vicia faba L. Major). Int. J. Agri. Biol. 6(2): 294-299.

Armstrong, E.L., P.W. Matthews, N.A. Fettell, D.J. Holding, L.G. Gaynor, C.J. Lisle and B.R. Cullis. 2008. Effects of plant density on the yield of field pea and faba bean varieties across southern and central NSW preliminary findings. Proceedings of 14th Agronomy Confer. 21-25 September. Adelaide, South Australia.

Auskalnis, A. and V. Dovydaitis. 1998. The dependence of pea crop density and producticity on seed rate and sowing time on the light loam. Zemdirbyste Mokslo Daebai. 63: 143-155.

Ayaz, S., B.A. McKenzie, G.D. Hill and D.L. McNeil. 2004. Variability in yield of four grain legume species in a 
subhumid temperate environment I. Yields and harvest index. J. Agr. Sci. 142: 9-19.

Baswana, K.S. and B.S. Saharan. 1993. Effect of row spacing and seed rate on pod yield of garden pea. Haryana J. Agron. 9: 93-95.

Berti, M. and S. Zwinger. 2011. Cool-season annual forages for hay in North Dakota. Forage Focus-Hay. p. 1-2.

Biswas, D., M. Haque and M. Rahman. 2012. Influence of plant population density on growthand yield of two black gram varieties. Pakistan J. Agr. 1(2-3): 83-85.

Braithwaite, R.A.I. 1982. Bodie bean responses to changes in plant density. Agron. J. 74: 593-596.

Davies, D.E., G.J. Berry, M.C. Heath and T.C.K. Dawkins. 1985. Pea (Pisum sativum L.). In: Grain Legume Crops. Ch. 5, ed. Summerfield, R.J. and Roberts, William Collins E.H., 147-198, Sons \& Co. Ltd. London.

Dwivedi, R.K., V.K. Singh, S.K. Choudhary, R.B.S. Sangar and R.P. Bajpai. 1998. Response of table pea (Pisum sativum L.) cultivars to sowing dates and seed rate under northern zone of chhattisgarh. M.P. Orissa J. Hort. 26: 23-25.

Heath, M.C. and P.D. Hebblethwaite. 1987. Precision drilling combining peas (Pisum sativum L.) of contrasting leaf types at varying densities. J. Agric. Sci.108 (2): 425-430.

Heath, M.C., C.M. Knott, C.J. Dyer and D. Rogers-Lewis. 1991. Optimum plant densities for three semi-leafless combining pea (Pisum sativum) cultivars under contrasting field conditions. Ann. Appl. Biol. 118: 671-688.

Joachim, H. and G. Jung. 1997. Analysis of forage fiber and cell walls in ruminant nutrition. Journal of Nutrition 127: 810813

Johnston, A.M., G.W. Clayton, G.P. Lafond, K.N. Harker, T.J. Hogg, E.N. Johnson, W.E. May and J.T. McConnell. 2002. Field pea seeding management. Can. J. Plant Sci. 82: 639644.

Jovaisiene, E., I. Bakstys and V. Jonusiene. 1998. The dependence of pea crop density and productivity on seed rate and sowing time in Western Lithuania. Zemdirbyste Mokslo Darbai. 63: 156-165.

Kadioglu, S. 2011. The effects of phosphate fertilization and bacteria inoculation on agricultural and morphological characteristics of some different (forage) pea cultivar. $155 \mathrm{p}$. (Not press Ph. D. Thesis).

Kebede, G., G. Assefa, A. Mengistu and F. Feyissa. 2014. Forage nutritive values of vetch species and their accessions grown under nitosol and vertisol conditions in the central highlands of Ethiopia. Livestock Res. Rur. Develop. 26(1): $1-14$.

Kiraz, A.B. 2011. Determination of relative feed value of some legume hays harvested at flowering stage. Asian J. Anim. Vet. Adv. 6(5): 525-530.

Knott, C.M. and S.J. Belcher. 1998. Optimum sowing dates and plant populations for winter peas (Pisum sativum). J. Agric. Sci. 131:449-454.

Kocer, A. and S. Albayrak. 2012. Determination of forage yield and quality of pea (Pisum sativum L.) mixtures with oat and barley. Turk. J. Field Crops. 17(1): 96-99.

Lithourgidis, A.S., I.B. Vasilakoglou, K.V. Dhima, C.A. Dordas and M.D. Yiakoulaki. 2006. Forage yield and quality of common vetch mixtures with oat and triticale in two seeding ratios. Field Crops Res. 99: 106-113.

Martin, I., J.L. Tenoria and L. Ayerbe. 1994. Yield, growth and water use of conventional and semi leafless peas in semiarid environments. Crop Sci. 34: 1576- 1583.
Robinson P., D. Putnam and S. Mueller. 1998. Interpreting your forage test report. Colifornia alfalfa and forage review. 1(2): $1-2$.

Tan, M., A. Koc and Z. Dumlu Gul. 2012. Morphological characteristics and seed yield of East Anatolian local forage pea (Pisum sativum ssp. arvense L.) ecotypes. Turk. J. Field Crops. 17(1): 24-30.

Tan, M., K. Kursun Kirc1 and Z. Dumlu Gul. 2014. Effects of row spacing and seeding rate on hay and seed yield of Eastern Anatolian forage pea (Pisum sativum ssp. arvense L.) ecotype. Turk. J. Field Crops. 19(1): 96-100.

Tawaha, A.M. and M.A. Turk. 2001. Effect of date and rate of sowing on yield and yield componenets of narbon vetch under semi-arid conditions. Acta Agron. Hungarica 49: 103-105.

Tekeli, A.S. and E. Ates. 2003. Yield and its components in field pea (Pisum arvense L.) lines. J. Central European Agric. 4(4): 313-317.

Timuragaoglu, K.A., A. Genc and S. Altınok. 2004. A research on forage and seed yields of forage pea lines under Ankara conditions. J. Agric. Sci.10(4): 457-461.

Townley Smith, L. and A.T. Wright. 1994. Field pea cultivar and weed response to crop seed rate in western Canada. Canadian J. Plant Sci. 74: 387-393.

Turk M., S. Albayrak and O. Yuksel. 2011. Effect of seeding rate on the forage yields and quality in pea cultivars of differing leaf types. Turk. J. Field Crops. 16(2): 137-141.

Uher D., Z. Stafa, S. Sikora and M. Blazinkov. 2008. Yield and quality of forage type pea lines and wheat mixtures. VII. Alps-Adria Scientific Workshop. 523-526.

Uzun, A. and E. Acikgoz. 1998. Effect of sowing season and seeding rate on the morphological traits and yield in pea cultivars of differing leaf types. J. Agron. Crop Sci. 181: 215-222.

Uzun, A., U. Bilgili, M. Sincik, I. Filya and E. Acikgoz. 2005.Yield and quality of forage type pea lines of contrasting leaf types. Europ. J. Agronomy. 22: 85-94

Uzun, F. 2010. Changes in hay yield and quality of bulbous barley at different phonological stages. Turk. J. Agric For. 34: $1-9$

Van Soest, P.J., J.B. Robertson and B.A. Lewis. 1991. Methods for dieatary fiber, neutral detergent fiber and nonstarch polysaccharides in relation to animal nutrition. J. Dairy Sci. 74: 3583-3597.

Yavuz, M., S. Iptas, V. Ayhan and Y. Karadag. 2009. Forage quality and nutritional problems caused by forage. 5.1. Quality analysis at forage and usage areas of forage. In: Forage General Chapter I, ed. Avcıŏlu, R., Hatipoğlu, R.ve Karadağ, Y., 163-172. T.C. Ministry of Agriculture and Rural Areas General Directorate for Agricultural Production and Development Publication, Izmir.

Yavuz, T., M. Sürmen and N. Cankaya. 2011. Effect of row spacing and seeding rate on yield and yield components of common vetch (Vicia sativa L.). J. Food Agr. Environ. 9 (1): 369-371.

Y1lmaz. S., A. Ozel, M. Atak and M. Erayman. 2015. Effects of seeding rates on competition indices of barley and vetch intercropping systems in the Eastern Mediterranean. Turk. J. Agric. For. 39: 135-143 